\title{
THE CHALLENGES IN THE HIGH CARBON FERROMANGANESE INDUSTRY AND PROSPECTS
}

\author{
Michel KALENGA WA KALENGA \\ University of Johannesburg, Faculty of Engineering and the Built Environment, School of Mining, Metallurgy \\ and Chemical Engineering, Johannesburg, South Africa, michelk@uj.ac.za
}

https://doi.org/10.37904/metal.2021.4087

\begin{abstract}
The production of High carbon ferromanganese industry worldwide is facing gigantic challenges due an everincreasing production cost that is mainly due to the yearly increase of electricity and the depletion of metallurgical coke. The power supply in some part of the world has become a challenge therefore impacting the productivity and slowing the growth of economies. Due to the depletion of metallurgical coke, alternative carbonaceous materials that would efficiently sustain the carbothermic reduction. The current paper depicts some of the challenges and presents some prospects and directions that are being tried as rescue measures. A number of laboratory bench-scale results are presented and enjoy being of good prospects.
\end{abstract}

Keywords: Metallurgy, High carbon ferromanganese, challenges, prospects

\section{INTRODUCTION}

Magnaese is one of the required additives in the from of ferroalloys to enhance steel properties. From the worldwide production of manganese, $90 \%$ is consumed in the steel industry. High carbon ferromanganese, refined ferromanganese, low carbon ferromanganese and silicomanganese are the four major groups of alloys marketed manganese alloys. The industrial practice for the production of manganese ferroalloys is based on carbothermic reduction of manganese oxides. Another process using aluminum to reduce manganese oxides was also developed [1]. Electric furnaces and Blast furnaces are used [2]. The heating process of the former is based on electrical energy and the reduction using coke as reducing agent. The later uses coke for supplying heat requirements and as reducing agent. The disadvantage remains with high coke consumption and high $\mathrm{MnO}$ content in the slag and the manganese reporting in the off-gases. Although it has been widely reported that electric furnaces present many advantages such as high yield of manganese form the manganese ore, consumption of carbon considerably reduced compared to Blast furnaces, ability to produced different types of alloys, it remains a great question to find a solution to is the increasing cost of production due to the everincreasing cost of energy.

\subsection{Manganese deposits}

Several manganese deposits are found in different countries worldwide with different mineralogical compositions. The deposits are located in the Kalahari Manganese Field (KMF). Two types of ores are found with one rich in carbonates and the other bearing predominantly braunite [3,4]. The manganese ore in Australia is rich in pyrolusite and cryptomelane [5], but some other are rich in psilomelane and hollandite with sometimes high in barium [6]. The Gabonese deposit to the Australian manganese deposit. The difference between the two is that the porosity is higher for the Gabonese deposit. The brazilian deposit is mainly composed of cryptomelane, todorokite and pyrolusite. China has the largest mine output averaging $22 \%$ containing high phosphorus and iron [7]. Kazakhstan and Ukraine have low grade compsed mainly by carbonates. Georgia has also low grade material while India has medium grade material in addition to low grade. The composition of the manganese ore plays a vital role during the carbothermic reduction of manganese [8]. To improve the 
recovery and the efficiency in energy consumption, a blend of manganese ores is applied when both electric and Blast furnaces are used.

Figure 1 below depicts the percentages of different ferroalloys produced by region.
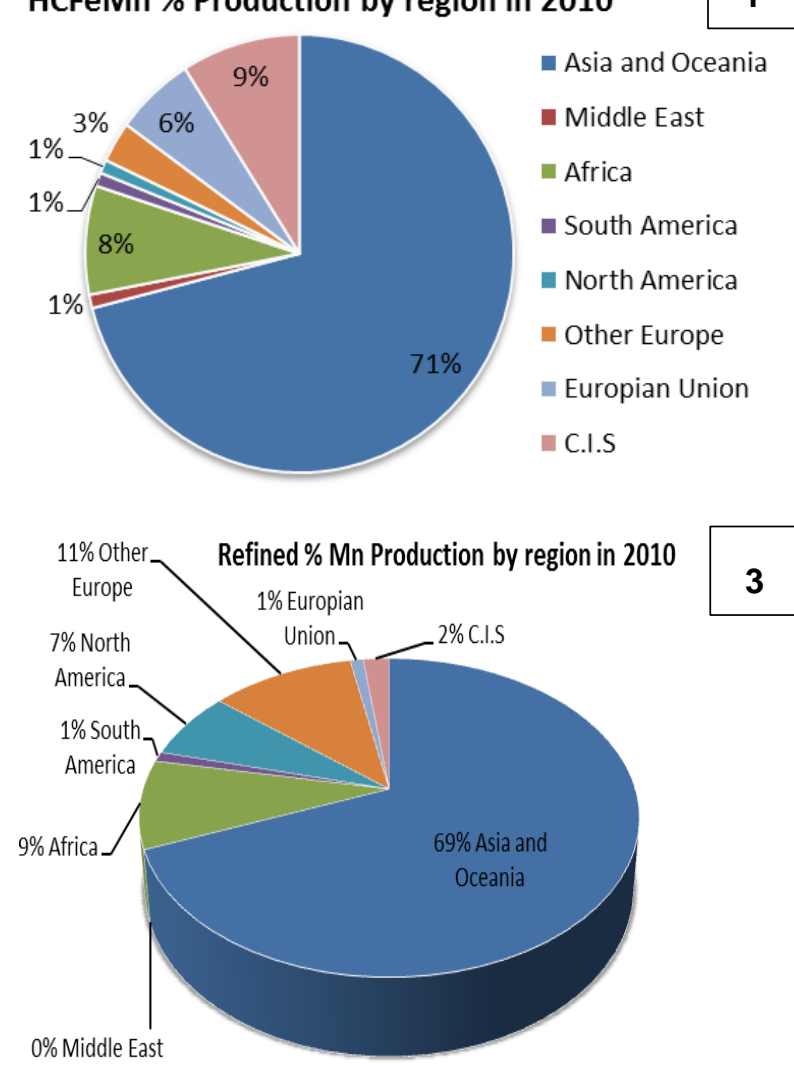
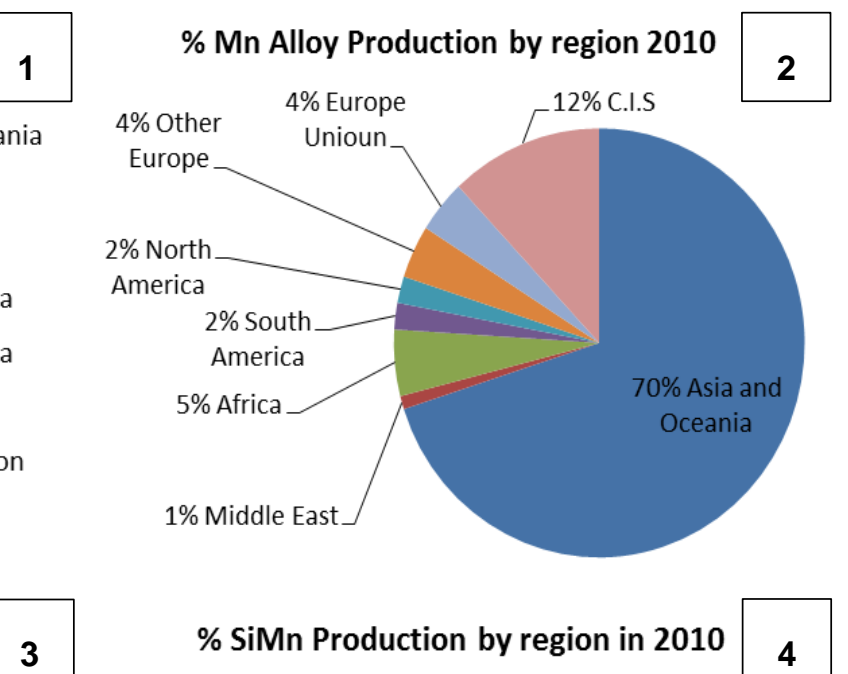

Asia and Oceania $\quad$ Middle East
South America $\quad$ Africa
Europian Union $\quad$ C.I.S

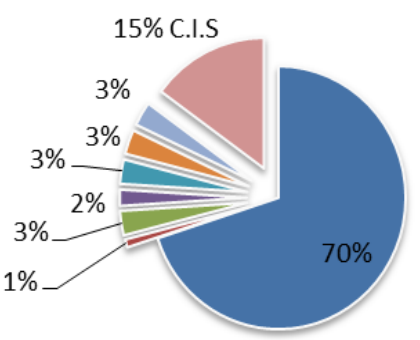

Figure 1 Percentage production of various ferroalloys by region in 2010 [2]

\subsection{Carbon materials}

Coal remains the main source of carbon. I submerged arc furnaces, coal cannot be used directly as reductant due to safety and environmental reasons. In order to select the reducing agent, a variety of considerations have to be taken into account namely availability, cost, process requirements, products requirements and gas emissions. The smelting productivity, reduction process and efficiency are affected by the physical properties of the carboneceous materials [10]. The energy consumption, the amount of reductants to use and the product quality are influenced by the chemical composition of the reductant used. The freight cost for charcoal is high because of its low weight. The freight price is based on the volume than the weight. The ferrosilicon industry has chosen the use of charcoal more advantageous due to low ash content. However, in the manganese industry, the use of charcoal is not easy. The leaning toward charcoal will make this commodity scarce, therefore new challenges are on the card. Also, with the metallurgical coke being now at high demand due to high outputs in the iron and steel industry, the scaricity of both metallurgical coke and charcoal pushes the manganese insdustry into looking at new materials and processing, ways of decreasing energy consumtpion, developping new technologies to takle environmental challenges that affect the profit margins in the manganese industry. 


\section{CHALLENGES IN THE MANGANESE INDUSTRY}

\subsection{Challenges due to mineralogical composition of the manganese ore}

\begin{tabular}{|c|c|c|c|c|c|}
\hline Reactions $25^{\circ} \mathrm{C}$ & $\mathrm{kmol}$ & & MJ & $\mathrm{kWh}$ & $\sum \mathrm{kWh}$ \\
\hline \multicolumn{6}{|l|}{ Drying } \\
\hline $\mathrm{H}_{2} \mathrm{O}_{(\mathrm{l})}=\mathrm{H}_{2} \mathrm{O}_{(\mathrm{g})}$ & 11.00 & & 484 & 134 & \\
\hline $\mathrm{H}_{2} \mathrm{O}+\mathrm{CO}=\mathrm{H}_{2}+\mathrm{CO}_{2}$ & 1.50 & & 4 & 1 & 135 \\
\hline \multicolumn{6}{|l|}{ Pre-reduction and calcination } \\
\hline $\mathrm{C}+\mathrm{CO}_{2}=2 \mathrm{CO}$ & 8.00 & & 1379 & 383 & 383 \\
\hline $\mathrm{CaCO}_{3}-\mathrm{CaO}+\mathrm{CO}_{2}$ & 2.20 & & 392 & 109 & \\
\hline $\mathrm{MgCO}_{3}=\mathrm{MgO}+\mathrm{CO}_{2}$ & 1.36 & & 141 & 39 & 148 \\
\hline $\mathrm{Fe}_{3} \mathrm{O}_{4}+4 \mathrm{CO}=3 \mathrm{Fe}+4 \mathrm{CO}_{2}$ & 0.83 & & -31 & -9 & \\
\hline $\mathrm{MnO}_{2}+\mathrm{CO}=\mathrm{MnO}+\mathrm{CO}_{2}$ & 9.50 & & -1407 & -391 & \\
\hline $\mathrm{Mn}_{3} \mathrm{O}_{4}+\mathrm{CO}-3 \mathrm{MnO}+\mathrm{CO}_{2}$ & 2.69 & & -137 & -38 & -438 \\
\hline \multicolumn{6}{|l|}{ Final reduction } \\
\hline $\mathrm{MnO}+\mathrm{C}=\mathrm{Mn}+\mathrm{CO}$ & 14.4 & & 3955 & 1099 & \\
\hline $\mathrm{SiO}_{2}+2 \mathrm{C}=\mathrm{Si}+2 \mathrm{CO}$ & 0.014 & & 9.7 & 2.7 & \\
\hline $\mathrm{C} \rightarrow \mathrm{Mn}_{7} \mathrm{C}_{3} *$ & 5.8 & & -211 & -59 & 1043 \\
\hline Total heat of reaction $\left(25^{\circ} \mathrm{C}\right)$ & & & & & 1271 \\
\hline Product enthalpies $\left(25-\mathrm{T}^{\circ} \mathrm{C}\right)$ & $\mathrm{kmol}$ & kg & MJ & $\mathrm{kWh}$ & $\sum \mathrm{kWh}$ \\
\hline \multicolumn{6}{|l|}{ Metal $1500^{\circ} \mathrm{C}(\mathrm{s} \rightarrow \mathrm{l})$} \\
\hline Mn $\quad 79.0 \%$ & 14.4 & 790 & 1138 & 316 & \\
\hline Fc $\quad 14.0 \%$ & 2.5 & 140 & 177 & 50 & \\
\hline \multirow[t]{2}{*}{ C $\quad 7.0 \%$} & 5.8 & 70 & 371 & 103 & 469 \\
\hline & & 1000 & & & \\
\hline \multicolumn{6}{|l|}{ Slag $1500^{\circ} \mathrm{C}(\mathrm{s} \rightarrow 1)$} \\
\hline $\mathrm{MnO} 34.6 \%$ & 3.19 & 226 & 392 & 109 & \\
\hline $\mathrm{SiO}_{2} \quad 26.5 \%$ & 2.88 & 173 & 316 & 88 & \\
\hline $\mathrm{Al}_{2} \mathrm{O}_{3} 11.5 \%$ & 0.74 & 75 & 217 & 60 & \\
\hline $\mathrm{CaO} \quad 18.8 \%$ & 2.19 & 123 & 339 & 94 & \\
\hline \multirow[t]{2}{*}{$\mathrm{MgO} \quad 8.6 \%$} & 1.39 & 56 & 194 & 54 & 405 \\
\hline & & 653 & & & \\
\hline \multicolumn{6}{|l|}{ Off-gas $200^{\circ} \mathrm{C}$} \\
\hline $\mathrm{CO}$ & 13.40 & & 69 & 19 & \\
\hline $\mathrm{CO}_{2}$ & 12.57 & & 90 & 25 & \\
\hline $\mathrm{H}_{2} \mathrm{O}$ & 9.5 & & 57 & 16 & \\
\hline $\mathrm{H}_{2}$ & 1.5 & & 8 & 2 & 62 \\
\hline Total product enthalpies $\left(25-\mathrm{T}^{\circ} \mathrm{C}\right)$ & & & 3368 & & 936 \\
\hline PROCESS total & & & & & 2207 \\
\hline
\end{tabular}

Figure 2 Typical example of mass and energy balance during high carbon ferromanganese [12]

The composition of raw material is a key player in the production of high carbon ferromanganese. Amongst other parameters are the $\mathrm{Mn} / \mathrm{Fe}$ ratio. The challenge that $\mathrm{Mn} / \mathrm{Fe}$ in a manganese ore is that low $\mathrm{Mn} / \mathrm{Fe}$ ratio leads to high coke consumption and high electrodes consumptions with low manganese recovery [11]. The moisture content, state of oxidation of manganese in the ore, any carbonates present in the manganese ore influence the mass and energy balances. Water evaporation, carbonates decomposition are high energy consumming steps in the production of high carbon ferromanganese while the presence of high manganese oxides in the ore is beneficial to the energy consumption because reduction of higher oxides is higly 
exothermic. A typical example of the energy balance and mass balance based on the mineralogy of the ore is presented in Figure 2 below. It transpires that water eveaporation alone is $6 \%$ of the energy consumption whereas carbonates decomposition amounts to $7 \%$ of the energy consumption. Moisture removal might be controlled same way for different manganese ores, but carbonates decomposition depends on the mineralogy of the ore. Further, it is noted that the presence of $\mathrm{MnO}_{2}$ in the ore has a positive contributing factor to the overal energy consumption. However, if one assumes that the manganese ore does not contain $\mathrm{MnO}_{2}$ but $\mathrm{Mn}_{2} \mathrm{O}_{3}$, the impact of the absence of $\mathrm{MnO}_{2}$ reduction to $\mathrm{Mn}_{2} \mathrm{O}_{3}$ is that the energy consumption will increase considerably. The consequence is the cost of production increases especially for electric furnaces due to everincreasing electricity price. This constituites a great challange because the composition of the ore is critical not only on the quality of the products, but on the cost of the process due to energy consumption. Reactions are grouped in exothermic and endothermic. Exothermic reactions are essentially reduction of $\mathrm{MnO}_{2}$ to $\mathrm{Mn}_{2} \mathrm{O}_{3}$, reduction of $\mathrm{Mn}_{2} \mathrm{O}_{3}$ to $\mathrm{Mn}_{3} \mathrm{O}_{4}$, reduction of $\mathrm{Mn}_{3} \mathrm{O}_{4}$ to $\mathrm{MnO}$, reduction of $\mathrm{Fe}_{3} \mathrm{O}_{4}$ to $\mathrm{Fe}, \mathrm{C}=\underline{\mathrm{C}}$ (dissolution of carbon into the molten metal) while Endothermic reactions are $\mathrm{MgCO}_{3}$ decomposition to $\mathrm{MgO}$ and $\mathrm{CO}_{2}$, water evaporation, $\mathrm{CaCO}_{3}$ decomposition to $\mathrm{CaCO}$ and $\mathrm{CO}_{2}$, Boudouard reaction $\left(\mathrm{C}+\mathrm{CO}_{2}=2 \mathrm{CO}\right)$, reduction of $\mathrm{MnO}$ to $\mathrm{Mn}$ (highly endothermic) and partial reduction of $\mathrm{SiO}_{2}$ to $\mathrm{Si}$ (reports to the metal). Furthermore, the quality of the burden is another factor is challanging. The permeability of the bed, when not well managed lead to poor gas circulation. This is governed by the composition of the feed. In case, sinters were made out of a manganese ore which contains carbonates, it may, after a certain time of storage encounter desagregation due to possibly occuled gas during sintering which took palce while calcining was also taking place. Occuled gas may also, if no desintegration took place before feeding the furnace, be liberated during reduction due to high temperature and lead to desintegration, therefore decrease the permeability of the bed.

\subsection{Challenges due to gas emissions}

Emissions emanating from off-gas are complicated to solve compared to those from dusts emissions. Two to three-stages wet scrubbers are used to collect uncombusted $\mathrm{CO}$ gas for closed manganese alloys furnaces [13-15]. Although nowadays most of the air pollution problems are solved satisfactorily, the main challenges remain with water pollution. The presence of heavy metals, polycyclic Aromatic Hydrocarbons (PAC), suspended solids and possibly dissolved cyanides is the major challenge. Additionally, the $\mathrm{CO} / \mathrm{CO}_{2}$ ratio in the off-gas is is important since it has a tremendous influence on the water $\mathrm{pH}$ value. This implies that the variation of reducing conditions has an impact on the acididty of water. Further, the presence of mercury in the off-gas is detrimental to the environment, therefore a number of processes for mercury removal have been required with new technologies being developped.

\section{NEW DIRECTIONS AND PROSPECTS}

In order to draw new directions a number of steps can be considered. Testing different new raw materials, testing new reductants that would improve the environmental impact of the ferromanganese industry, Development of new technologies: new reactors for ferroalloy production and energy, introduction of artificial intelligence to improve the prediction and monitoring of processes, vaste campain of recrutement of scientists to refelect on the future without coke and coal can be envisaged to find new and effiecient direction.

\section{SOME INDICATIONS ON NEW MATERIAL}

A number of focused investigations on the use of new material are ongoing. Fuel biobased have been tested to replace coke breeze in the iron ore sintering process. This has been driven by reports that the reactivity of biobased fuels is considerably higher than that of coke breeze due mainly to their higher porosity and surface area [16]. Partial replacement of coke breeze during ironmaking in the Balst furnace in the sintering section has been found successful [16]. Some studies on the possible use of biomass using the South African manganese ores were conducted and as preliminary results were generated. The use of raw macadamia nut 
shells for the reduction of manganese ore has been tested. It was found that macadamia nut shells have great potentials of replacing the conventional reductants used so far. The separation of slag from the metal remains a challenging factor and needs imporvement [17]. Pam Kernel Shells were also tested as a replacement of coke. Results have shown good prospect. The extraction of manganese amounted to close to $50 \%$ whereas it was around $45 \%$ when charcoal was used [18]. The prospect of replacing current generic reducing agents is considerable coupled with further detailed investigations on sizes and possible improvements of the raw materials used as coke repalcement. Their impact on the recovery and the quality of end products needs thourough research and possibly innovation technology should accompany the walk on the new road. Not only that new carboneceous materials should only be used as reductants, but test their contribution toward energy consumption as well.

\section{CONCLUSION}

Current challenges that the manganese industry if faced with, a new dynamic, trials and errors can be permitted to find new ways and innovative solutions to metallurgical coke replacement, reducing agents consumption with impact on energy consumption. Organizing discussion and research groups around these topics would considerably contribute to accelerating findings to these major challenges that the manganese industry encounter today he paper must contain conclusion. The conclusion should summarize the findings and explain the implications of the paper. Conclusion contains no new data or findings.

\section{ACKNOWLEDGEMENTS}

\section{The author thanks all the colleagues for constructive discussions during the drafting of this paper to challenge the challenges the manganese industry is facing.}

\section{REFERENCES}

[1] LEE, Y.E. and TANGSTAD, M. Electric parameters for an efficient smelting performance of HCFeMn alloy. Proceedings of INFACONXII. Helsinki, Finland, 6-9 June 2010, pp. 569-578.

[2] BASSON, J., CURR, T.R., and GERICKE, W.A. South Africa's ferro alloys industry - present status and future outlook. Proceedings of INFACONXI. New Delhi, India, 18-21 February 2007.

[3] KLEYENSTUBER, A.S.E. A review of geology and mining of the Kalahari manganese field. Proceedings of the $12^{\text {th }}$ CMMI (Council Mining and Metallurgical Institutions) Congress. Johannesburg, 3-7 May 1982, pp. 213-220.

[4] VILLIERS, J.P.R. A Mineralogical Investigation of Mamatwan and Wessels Manganese Ores. Report No. 1920. Randburg: National Institute for Metallurgy, p. 15.

[5] FRAZER, W.E. \& BELCHER, C.B. Mineralogical studies of the groote Eylandt manganese ore deposites. Proceedings of the Australian Institute of Mining and Metallurgy. 1975, vol. 254, pp. 29-36.

[6] OSTWALD, J. Mineralogy of the Groote Eylandt manganese oxides-A review. Ore Geology Review. 1988, vol. 4, no. 1-2, pp.3-45.

[7] CHEN, R. \& QIN, B. The manganese Ore Resources in China and their Prospecting. China geological Survey. International EIMn Sustainable Development Forum, Chogqing, 2003.

[8] KALENGA, M., XIAOWEI, P., AND TANGSTAD, M. Manganese alloys production: Impact of chemical compositions of raw materials on the energy and materials balance. Proceedings of INFACONXIII, Almaty, Kazakhstan. 9-12 June 2013, pp. 647-654.

[9] STEENKAMP, J.D., BASSON, J. The manganese ferroalloys industry in southern Africa. Journal of the Southern African Institute of Moning and Metallurgy. 2012, vol. 113, no. 8, pp. 667-676.

[10] SAHAJWALLA, V., DUBIKOVA, M. \& KAHNNA, R. Reductant characterization and slection: Implications for ferroalloy processing. Proceedings of the Tenth International Congress on Ferroalloys (INFACON 10). Cape Town, 1-4 February 2004, pp. 351-362. 
[11] GHALI, S., EL-FARAMAWY, H., AHMED, A., NABIL, S. Parameters Affecting the Production of High Carbon Ferromanganese in Closed Submerged Arc Furnace. Journal of Minerals and Materials Characterization and Engineering. 2012, vol. 11, no. 1, pp. 1-20.

[12] OLSEN, S.E., TANGSTAD, M. \& LINDSTAD, T. Production of Manganese Ferroalloys. Tapir academic press, 2007, p. 166.

[13] LOMO, A. Pollution problems with electric reduction furnaces in the ferroalloy industry. Proceedings of the First International Congress of Ferroalloys (INFACON 74). Johannesburg, 22-26 April 1974, pp. 251-257.

[14] ERICKSEN, E. \& LOMO, A. Pollution controland energy recovery in the ferroalloy industry. The Institution of Mining and Metallurgy. Extraction Metallurgy 85, Symposium. London, 9-12 September 1985, pp. 445-472.

[15] HUNSBEDT, L., COWX, P.M., FLATABO, R., JOHANSEN, K.E., \& BUSTNES, J.A. Environmental challenges for Norwegian Mn-Industry. Proceedings of the Eleventh International Congress on Ferroalloys (INFACON XI). Dheli, February 2007, pp. 446-456.

[16] KHANNA, R., LI, K., WANG, Z., SUN, M., ZHANG, J., MUKHERJEE, P.S. Biomass in Iron and Steel Industry. Char and carbon materials, Production, Characterization and Applications. 2019, pp. 429-446.

[17] KALENGA, MK., NYEMBWE, D.K., MULABA-BAFUBIANDI, A. Biomass Reduction of manganese ore in presence of carbon m onoxide. In: 5th International Conference on Recent Trends in Structural Materials, COMAT 2018. Pilsen, Czech Republic, 14 -16 November 2018.

[18] SUPRIYATNA, I.Y., ZULHAN, Z. and TRIAPRIANI, Y. The ferromanganese production using Indonesian lowgrade manganese ore using charcoal and palm kernel shell as reductant in mini electric arc furnace. In: Mineral Processing and Technology International Conference. IOP Conf. Series: Materials Science and Engineering. [online]. 2018, vol. 285, 012022. Available from: https://doi.org/10.1088/1757-899X/285/1/012022. 